\title{
Synthesis, evaluation and molecular modelling studies of some novel 3-(3,4-dihydroisoquinolin-2(1H)-yl)- $N$-(substituted- phenyl)propanamides as HIV-1 non-nucleoside reverse transcriptase inhibitors
}

\author{
S MURUGESAN ${ }^{1, *}$, SWASTIKA GANGULY ${ }^{1}$ and GIOVANNI MAGA ${ }^{2}$ \\ ${ }^{1}$ Department of Pharmaceutical Sciences, Birla Institute of Technology, Mesra, Ranchi 835215 \\ ${ }^{2}$ DNA Enzymology and Molecular Virology Section, Instituto Di Genetica Molecolare, Pavia, \\ Italy-207-27100 \\ e-mail: murugesaa789@yahoo.co.in, swastikaganguly@bitmesra.ac.in
}

MS received 2 February 2009; revised 8 May 2009; accepted 26 August 2009

\begin{abstract}
A novel series of fifteen 3-(3,4-dihydroisoquinolin-2(1H)-yl)- $N$-(substituted phenyl) propanamides 3(a-o) were synthesized by reacting the corresponding 3-chloro- $N$-(aryl) propanamides 2(a-o) with 1,2,3,4-tetrahydroisoquinoline 1 in acetonitrile. The compounds have been characterized on the basis of elemental analysis and spectral data. All the compounds were evaluated for their HIV-1 RT inhibitory activity. Among the synthesized compounds, 3-(3,4-dihydroisoquinolin-2(1H)-yl)- $N$ - $O$-tolyl propanamide 3d and 3-(3,4-dihydroisoquinolin-2(1H)-yl)- $N$-(2,4,6-tribromophenyl)propanamide 3f were identified as significant inhibitors of HIV-1 reverse transcriptase with $56 \%$ and $43 \%$ residual RT activity respectively at the final concentration of $40 \mu \mathrm{M}$ when compared with the standard drug Efavirenz. Docking studies with HIV-1 RT (PDB ID 1rt2) were also performed in order to investigate the binding pattern of these compounds.
\end{abstract}

Keywords. HIV-1 reverse transcriptase (HIV-1 RT); non-nucleoside reverse transcriptase inhibitor (NNRTI); docking; autodock; 1,2,3,4-tetrahydroisoquinoline.

\section{Introduction}

Acquired immuno deficiency syndrome (AIDS) is one of the most serious pandemic public health challenges since $1981 .{ }^{1}$ Human immuno deficiency virus (HIV) has been identified as the probable causative agent for AIDS. ${ }^{2}$ HIV-1 is a retrovirus and the genome in the virion is encoded in single stranded RNA. ${ }^{3}$ In an infected cell, the viral RNA is reverse transcribed to produce a double stranded DNA provirus by an enzyme known as DNA polymerase or reverse transcriptase (RT) which is able to insert itself into the host DNA. ${ }^{4}$ Because of the vital role of RT to HIV replication, inhibitor of this enzyme is one of the major potential attractive targets in the treatment of AIDS ${ }^{5-8}$ In general, the inhibitors of HIV-1 RT are classified into two main categories: nucleoside/nucleotide inhibitors (NRTIs) and nonnucleoside inhibitors (NNRTIs) ${ }^{9-13}$ NRTIs are sub-

\footnotetext{
*For correspondence
}

strate analogs of normal nucleotides that act competitively at the catalytic site of HIV-1 RT and there by terminating DNA synthesis, whereas NNRTIs are a chemically diverse group of compounds that noncompetitively bind to the unique allosteric hydrophobic binding pocket located about $10 \AA$ away from the RT DNA polymerase active catalytic site and $60 \AA$ from the RT RNase $\mathrm{H}$ active site. NNRTI binding induces rotamer conformational changes in some residues and makes the thumb region more rigid and thereby force the RT subunits into an inactive conformation. ${ }^{14-16}$ When compared to NRTIs, NNRTIs have the advantage of high potency, low toxicity, high selectivity and specificity as well as they will not interfere with the normal function of other host DNA polymerases. ${ }^{6}$ The efficacy of NNRTIs is decreased due to emergence of drug resistance mutations. To overcome these difficulties novel NNRTIs are searched by modifying the existing drug classes with appropriate pharmacophoric requirements. Earlier studies reveals that, more than 
30 different classes of NNRTIs have some features in common, that is, the overall structure may be considered reminiscent of a butterfly with hydrophilic centre ('body') and two hydrophobic outskirts ('wings'). ${ }^{17-20}$

Compounds having isoquinoline moiety exhibit potent antiviral, ${ }^{21-23}$ anti-tubercular, ${ }^{24-27}$ antifungal, ${ }^{28-29}$ antiprotozoal, antimalarial, ${ }^{30-45}$ and anticancer ${ }^{46}$ activities since ancient days. An extensive perusal of literatures showed that, little work has been done on synthetic tetrahydroisoquinolines as NNRTIs. In view of these facts and our continued interest in the chemistry of tetrahydroisoquinolines, we report the synthesis of some novel 3-(3,4-dihydroisoquinolin2(lH)-yl)- $N$-(substituted-phenyl)propanamides 3 with 'butterfly-like' congeners, evaluation for their HIV1 reverse transcriptase inhibitory activity and docking studies of the active compounds $\mathbf{3} \mathbf{d}$ and $\mathbf{3 f}$ on the HIV-1-reverse transcriptase enzyme (PDB entry 1RT2). All the newly synthesized compounds were designed based on the derived pharmacophoric model $^{19-20}$ with acetamide moiety $(-\mathrm{CH} 2-\mathrm{CO}-\mathrm{NH}-)$ constituting the 'body' and the aryl rings of isoquinoline and substituted aromatic amines constituting the 'wings'.

\section{Experimental}

\subsection{Materials, methods and instruments}

Melting points were taken in open capillaries on Thomas Hoover melting point apparatus and are uncorrected. Infrared spectra were recorded on $\mathrm{KBr}$ disks on a Shimadzu FTIR series 1020 spectrometer. ${ }^{1} \mathrm{H}$ NMR spectra were recorded on a Jeol D$300 \mathrm{MHz}$ Bruker FT-NMR spectrometer using $\mathrm{CDCl}_{3}$ as solvent. Mass spectral data were obtained on a Jeol D-300 spectrometer using Fast Atom Bombardment (FAB positive). Elemental analysis was performed on a Vario Elementor $\mathrm{C}, \mathrm{H}, \mathrm{N}$ analyser. Compounds $\mathbf{2 a - 0}$ were prepared according to the literature method. ${ }^{47}$ The reactions were monitored by thin layer chromatography (TLC) carried out on activated silica gel coated plates and the solvent system used was chloroform:benzene : methanol $(3: 0 \cdot 3: 0 \cdot 1)$.

2.1a Preparation of 3-(3,4-dihydroisoquinolin2(1H)-yl)-N-phenyl propanamide (3a): To a solution of 1,2,3,4-tetrahydroisoquinoline $(0.012 \mathrm{~mol}) \mathbf{1}$ in $16.7 \mathrm{ml}$ of acetonitrile was added 3-chloro- $\mathrm{N}$ - phenyl propanamide $(0.012 \mathrm{~mol}) \mathbf{2 a}$ and triethylamine $(0.024 \mathrm{~mol})$ drop-wise and refluxed for $8 \mathrm{~h}$. The reaction mixture was then cooled, poured into crushed ice and basified with solid potassium carbonate. The resulting precipitate was filtered, washed with water, further washed with n-hexane, dried and recrystallized from ethanol to yield colourless crystals of $\mathbf{3 a}$.

IR $(\mathrm{KBr})\left(\mathrm{cm}^{-1}\right): 3298(\mathrm{NH}$ stretching of aromatic secondary amide), 1662 (C=O stretching), 1323 (CN stretching of aliphatic amine).

${ }^{1} \mathrm{H}$ NMR $\left(\mathrm{CDCl}_{3}, 300 \mathrm{MHz}\right): \delta 6 \cdot 9-7 \cdot 6(9 \mathrm{H}, m$, $\mathrm{Ar} \underline{\mathrm{H}}), 3.5\left(2 \mathrm{H}, t,-\mathrm{N}-\mathrm{C}_{2}-\mathrm{CH}_{2}-\mathrm{CONH}\right), 2.9(2 \mathrm{H}, t$, $\left.\mathrm{N}-\mathrm{CH}_{2}-\mathrm{CH}_{2}-\mathrm{CONH}\right), 2.7\left(2 \mathrm{H}, t, \mathrm{~N}-\mathrm{C}_{2}-\mathrm{CH}_{2}-\mathrm{Ar}\right)$; $2 \cdot 3\left(2 \mathrm{H}, t, \mathrm{~N}-\mathrm{CH}_{2}-\mathrm{C}_{2}-\mathrm{Ar}\right), 2 \cdot 2\left(2 \mathrm{H}, s, \mathrm{~N}-\mathrm{C}_{2}\right)$. MS: $m / z 280\left[\mathrm{M}^{+}, \mathrm{C}_{18} \mathrm{H}_{20} \mathrm{~N}_{2} \mathrm{O},(18)\right], 281$ (100), 279 (25), 203 (10), 188 (15), 160 (12), 148 (18), 146 (63), 134 (15), 132 (33) and $120(18)$.

$2.1 \mathrm{~b} \quad 3-(3,4-D i h y d r o i s o q u i n o l i n-2(1 H)-y l)-N-(2-c h l o-$ rophenyl)propanamide (3b): IR $(\mathrm{KBr}) \quad\left(\mathrm{cm}^{-1}\right)$ : 3336 ( $\mathrm{NH}$ stretching of aromatic secondary amide), 1680 ( $\mathrm{C}=\mathrm{O}$ stretching), 1350 ( $\mathrm{CN}$ stretching of aliphatic amine), 756 (C-Cl stretching).

2.1c 3-(3,4-Dihydroisoquinolin-2(1H)-yl) $\quad \mathrm{N}-(3-$ chlorophenyl)propanamide (3c): $\operatorname{IR}(\mathrm{KBr})\left(\mathrm{cm}^{-1}\right)$ : 3335 (NH stretching of aromatic secondary amide), 1660 ( $\mathrm{C}=\mathrm{O}$ stretching), 1330 ( $\mathrm{CN}$ stretching of aliphatic amine), 783 (C-Cl stretching).

\section{1d 3-(3,4-Dihydroisoquinolin-2(1H)-yl)-N-o-tolyl} propanamide (3d): $\quad \mathrm{IR}(\mathrm{KBr}) \quad\left(\mathrm{cm}^{-1}\right): 3228 \quad(\mathrm{NH}$ stretching of aromatic secondary amide), $1653(\mathrm{C}=\mathrm{O}$ stretching), 1303 (CN stretching of aliphatic amine), 2980 and $1498 \quad\left(\mathrm{C}-\mathrm{CH}_{3}\right.$ stretching $) .{ }^{1} \mathrm{H} \quad \mathrm{NMR}$ $\left(\mathrm{CDCl}_{3}, 300 \mathrm{MHz}\right): \delta 8.8(s, 1 \mathrm{H}, \quad \mathrm{N} \underline{\mathrm{H}}), 6.8-7.7$ $(m, 9 \mathrm{H}, \operatorname{Ar} \underline{\mathrm{H}}), 3.8\left(s, 2 \mathrm{H}, \mathrm{N}-\mathrm{C}_{2}-\mathrm{Ar}\right), 2.9(t, 4 \mathrm{H}$, $\left.\mathrm{N}-\mathrm{C}_{2}-\underline{\mathrm{CH}}_{2}-\mathrm{Ar}\right), 3.0\left(t, 2 \mathrm{H}, \underline{\mathrm{C}}_{2}\right), 2.7\left(t, 2 \mathrm{H}, \underline{\mathrm{CH}}_{2}\right)$, $1.9\left(s\right.$ 3 H Ar- $\left.\underline{\mathrm{CH}}_{3}\right), \mathrm{MS}: m / z 294\left[\mathrm{M}^{+}, \mathrm{C}_{19} \mathrm{H}_{22} \mathrm{~N}_{2} \mathrm{O}\right.$, (30)], 295 (100), 293 (75), 146 (82), 132 (70) and 91 (30).

2.1e 3-(3,4-Dihydroisoquinolin-2(1H)-yl)-N-(4-chlorophenyl)propanamide (3e): $\operatorname{IR}(\mathrm{KBr})\left(\mathrm{cm}^{-1}\right): 3483$ (NH stretching of aromatic secondary amide), 1640 ( $\mathrm{C}=\mathrm{O}$ stretching), 1338 ( $\mathrm{CN}$ stretching of aliphatic amine), $742(\mathrm{C}-\mathrm{Cl}$ stretching $) .{ }^{1} \mathrm{H}$ NMR $\left(\mathrm{CDCl}_{3}\right.$, $300 \mathrm{MHz}): \delta 11.10(1 \mathrm{H}, \mathrm{s}, \mathrm{NH}), 7 \cdot 70-7.32(9 \mathrm{H}, m$, $\mathrm{Ar}-\underline{\mathrm{H}}), 3.80\left(2 \mathrm{H}, s, \mathrm{~N}-\mathrm{C}_{2}-\mathrm{Ar}\right), 2.94-2.89(4 \mathrm{H}, m$, $\left.\mathrm{N}-\underline{\mathrm{CH}}_{2}-\underline{\mathrm{CH}}_{2}-\mathrm{Ar}\right), 3.03-3.00 \quad\left(2 \mathrm{H}, t, \mathrm{~N}-\mathrm{CH}_{2}-\mathrm{C}_{2}-\right.$ 
$\mathrm{CO}), 2.65-2.61\left(2 \mathrm{H}, t, \mathrm{~N}-\mathrm{CH}_{2}-\mathrm{CH}_{2}-\mathrm{CO}\right) . \mathrm{MS}: \mathrm{m} / z$ $315\left[\mathrm{M}^{+}, \mathrm{C}_{18} \mathrm{H}_{19} \mathrm{~N}_{2} \mathrm{OCl},(100)\right], 316$ (30), 314 (20), $155(20), 146(90)$ and $132(80)$.

2.1f 3-(3,4-Dihydroisoquinolin-2(1H)-yl)-N-(2,4,6tribromophenyl)propanamide (3f): $\operatorname{IR}(\mathrm{KBr})\left(\mathrm{cm}^{-1}\right)$ : 3282 ( $\mathrm{NH}$ stretching of aromatic secondary amide), 1664 (C=O stretching), 1360 (CN stretching of aliphatic amine), 601 (C-Br stretching).

\section{$2.1 \mathrm{3} 3-(3,4-D i h y d r o i s o q u i n o l i n-2(1 H)-y l)-N-(2-$} hydroxyphenyl)propanamide (3g): $\quad \mathrm{IR}(\mathrm{KBr})\left(\mathrm{cm}^{-1}\right)$ : 3650 (Phenolic $-\mathrm{OH}$ stretching), 3360 (NH stretching of aromatic secondary amide $), 1635(\mathrm{C}=\mathrm{O}$ stretching), 1440 (OH stretching), 1360 (CN stretching of aliphatic amine).

$2.1 \mathrm{~h} \quad 3-(3,4-D i h y d r o i s o q u i n o l i n-2(1 H)-y l)-N-(3-$ hydroxhphenyl)propanamide (3h): $\mathrm{IR}(\mathrm{KBr})\left(\mathrm{cm}^{-1}\right)$ : 3566 (phenolic $-\mathrm{OH}$ stretching), 3481 ( $\mathrm{NH}$ stretching of aromatic secondary amide $), 1660(\mathrm{C}=\mathrm{O}$ stretching), 1400 ( $\mathrm{OH}$ stretching), 1320 (CN stretching of aliphatic amine).

$2.1 \mathrm{i}$ 3-(3,4-Dihydroisoquinolin-2(1H)-yl)-N-(2-nitrophenyl)propanamide (3i): $\operatorname{IR}(\mathrm{KBr}) \quad\left(\mathrm{cm}^{-1}\right): 3320$ (NH stretching of aromatic secondary amide), 1680 $\left(\mathrm{C}=\mathrm{O}\right.$ stretching), $1579\left(\mathrm{C}-\mathrm{NO}_{2}\right.$ stretching), 1305 (CN stretching of aliphatic amine).

$2.1 \mathrm{j} \quad 3-(3,4-D i h y d r o i s o q u i n o l i n-2(1 H)-y l)-N-(4-n i t r o-$ phenyl)propanamide $(\mathbf{3 j}): \quad \operatorname{IR}(\mathrm{KBr}) \quad\left(\mathrm{cm}^{-1}\right): 3473$ ( $\mathrm{NH}$ stretching of aromatic secondary amide), 1680 (C=O stretching), $1560 \quad\left(\mathrm{C}-\mathrm{NO}_{2}\right.$ stretching), 1336 (CN stretching of aliphatic amine).

$2.1 \mathrm{k} \quad 3-(3,4-D i h y d r o i s o q u i n o l i n-2(1 H)-y l)-N-m-t o l y l$ propanamide (3k): $\quad \operatorname{IR}(\mathrm{KBr}) \quad\left(\mathrm{cm}^{-1}\right): 3309 \quad(\mathrm{NH}$ stretching of aromatic secondary amide), 2891 (C- $\mathrm{CH}_{3}$ stretching), $1670(\mathrm{C}=\mathrm{O}$ stretching $), 1332$ (CN stretching of aliphatic amine).

2.11 3-(3,4-Dihydroisoquinolin-2(1H)-yl)-N-p-tolyl propanamide (3I): $\quad \mathrm{IR}(\mathrm{KBr})\left(\mathrm{cm}^{-1}\right): 3284(\mathrm{NH}$ stretching of aromatic secondary amide), 2821 (C- $\mathrm{CH}_{3}$ stretching), 1653 (C=O stretching), 1320 (CN stretching of aliphatic amine).

$2.1 \mathrm{~m} \quad 3-(3,4-D i h y d r o i s o q u i n o l i n-2(1 H)-y l)-N-(2,4-$ dimethyphenyl)propanamide (3m): $\operatorname{IR}(\mathrm{KBr})\left(\mathrm{cm}^{-1}\right)$ : 3290 (NH stretching of aromatic secondary amide),
$2887\left(\mathrm{C}-\mathrm{CH}_{3}\right.$ stretching $), 1647 \quad(\mathrm{C}=\mathrm{O}$ stretching $)$, 1379 (CN stretching of aliphatic amine).

2.1n 3-(3,4-Dihydroisoquinolin-2(1H)-yl)-N-(4methoxyhenyl)propanamide (3n): $\operatorname{IR}(\mathrm{KBr})\left(\mathrm{cm}^{-1}\right)$ : 3306 ( $\mathrm{NH}$ stretching of aromatic secondary amide), 1660 ( $\mathrm{C}=\mathrm{O}$ stretching), 1354 (CN stretching of aliphatic amine), 1160 and 1031 (C-O-C stretching).

2.10 3-(3,4-Dihydroisoquinolin-2(1H)-yl)-N-(4ethoxyphenyl)propanamide (3o): $\mathrm{IR}(\mathrm{KBr})\left(\mathrm{cm}^{-1}\right)$ : 3480 ( $\mathrm{NH}$ stretching of aromatic secondary amide), $1680(\mathrm{C}=\mathrm{O}$ stretching), $1360(\mathrm{CN}$ stretching of aliphatic amine), 1219 and 1040 (C-O-C stretching).

\subsection{HIV-1 RT RNA dependent DNA polymerase activity assay}

All the synthesized compounds were evaluated for HIV-1 RT inhibitory activity by using HIV-1 RT RNA dependent DNA polymerase activity assay. ${ }^{48}$ Efavirenz was used as the standard. Poly(rA)/ oligo(dT) was used as a template for the RNAdependent DNA polymerase reaction by HIV-1 RT, either wt or carrying the mutations. For the activity assay, a $25 \mu \mathrm{l}$ final reaction volume contained TDB buffer (50 mM Tris-HCl (pH 8.0), $1 \mathrm{mM}$ dithiothreitol (DTT), $0.2 \mathrm{mg} / \mathrm{ml}$ bovine serum albumin (BSA), $2 \%$ glycerol), $10 \mathrm{mM} \mathrm{MgCl}_{2}, 0.5 \mathrm{mg}$ of $\operatorname{poly}(\mathrm{rA})$ : oligo(d $T)_{10: 1}\left(0.3 \mathrm{mM} \mathrm{3}^{\prime}-\mathrm{OH}\right.$ ends $), 10 \mathrm{mM}^{3}[\mathrm{H}]-$ dTTP $(1 \mathrm{Ci} / \mathrm{mmol})$ and finally, introduced into tubes containing aliquots of different enzyme concentrations ( 5 to $10 \mathrm{nM} \mathrm{RT}$ ). After incubation at $37^{\circ} \mathrm{C}$ for indicated time, $20 \mu \mathrm{L}$ from each reaction tube were spiked on glass fibre filters $\mathrm{GF} / \mathrm{C}$ and immediately, immersed in 5\% ice-cold trichloroacetic acid (TCA) (AppliChem GmbH, Darmstadt). Filters were washed three times with 5\% TCA and once with ethanol for $5 \mathrm{~min}$, then dried and, finally, added with EcoLume ${ }^{\circledR}$ Scintillation cocktail (ICN, Research Products Division, Costa Mesa, CA USA), to detect the acidprecipitable radioactivity by PerkinElmer ${ }^{\circledR}$ Trilux MicroBeta 1450 Counter.

\subsection{Computational studies}

All computational studies were carried out using Autodock 4.0.1 $1^{49-52}$ installed in a single machine running on a $3.4 \mathrm{GHz}$ Pentium 4 processor with $512 \mathrm{MB}$ RAM and $80 \mathrm{~GB}$ hard disk with Red Hat 
Table 1. Physical characterization data of compounds 3a-0.

\begin{tabular}{|c|c|c|c|c|c|c|c|}
\hline \multirow[b]{2}{*}{ Compound } & \multirow{2}{*}{$\begin{array}{l}\text { Molecular } \\
\text { formula }\end{array}$} & \multirow[b]{2}{*}{ Mol. wt. } & \multirow[b]{2}{*}{ m.p. $\left({ }^{\circ} \mathrm{C}\right)$} & \multirow[b]{2}{*}{ Yield (\%) } & \multicolumn{3}{|c|}{ Calculated (found) } \\
\hline & & & & & $\mathrm{C}$ & $\mathrm{H}$ & $\mathrm{N}$ \\
\hline $3 \mathbf{a}$ & $\mathrm{C}_{18} \mathrm{H}_{20} \mathrm{~N}_{2} \mathrm{O}$ & $280 \cdot 37$ & $165-170$ & 82 & $77 \cdot 11(77 \cdot 13)$ & $7 \cdot 19(7 \cdot 16)$ & $9.79(9.77)$ \\
\hline $\mathbf{3 b}$ & $\mathrm{C}_{18} \mathrm{H}_{19} \mathrm{~N}_{2} \mathrm{OCl}$ & $314 \cdot 82$ & $80-88$ & 97 & $68.67(68.70)$ & $6 \cdot 08(6 \cdot 06)$ & $8.90(8 \cdot 89)$ \\
\hline $3 c$ & $\mathrm{C}_{18} \mathrm{H}_{19} \mathrm{~N}_{2} \mathrm{OCl}$ & $314 \cdot 82$ & $65-70$ & 95 & $68.67(68.66)$ & $6 \cdot 08(6 \cdot 09)$ & $8 \cdot 90(8 \cdot 94)$ \\
\hline 3d & $\mathrm{C}_{19} \mathrm{H}_{22} \mathrm{~N}_{2} \mathrm{O}$ & $294 \cdot 40$ & $98-104$ & 75 & $77 \cdot 52(77 \cdot 50)$ & $7 \cdot 53(7.56)$ & $9 \cdot 52(9 \cdot 48)$ \\
\hline $3 \mathbf{e}$ & $\mathrm{C}_{18} \mathrm{H}_{19} \mathrm{~N}_{2} \mathrm{OCl}$ & $314 \cdot 82$ & $78-82$ & 89 & $68.67(68.68)$ & $6 \cdot 08(6 \cdot 10)$ & $8.90(8.91)$ \\
\hline 3f & $\mathrm{C}_{18} \mathrm{H}_{17} \mathrm{~N}_{2} \mathrm{OBr}_{3}$ & $517 \cdot 06$ & $90-94$ & 84 & $41 \cdot 81(41.84)$ & $3 \cdot 31(3 \cdot 29)$ & $5.42(5 \cdot 39)$ \\
\hline $3 g$ & $\mathrm{C}_{18} \mathrm{H}_{20} \mathrm{~N}_{2} \mathrm{O}_{2}$ & $296 \cdot 37$ & $82-90$ & 98 & $72.95(72.93)$ & $6 \cdot 80(6 \cdot 82)$ & $9.45(9.42)$ \\
\hline $3 \mathbf{h}$ & $\mathrm{C}_{18} \mathrm{H}_{20} \mathrm{~N}_{2} \mathrm{O}_{2}$ & $296 \cdot 37$ & $108-112$ & 98 & $72.95(72.98)$ & $6 \cdot 80(6 \cdot 79)$ & $9.45(9.47)$ \\
\hline $3 \mathbf{i}$ & $\mathrm{C}_{18} \mathrm{H}_{19} \mathrm{~N}_{3} \mathrm{O}_{3}$ & $325 \cdot 37$ & 84-90 & 82 & $66 \cdot 45(66 \cdot 46)$ & $5 \cdot 89(5 \cdot 91)$ & $12 \cdot 91(12 \cdot 90)$ \\
\hline $3 \mathbf{j}$ & $\mathrm{C}_{18} \mathrm{H}_{19} \mathrm{~N}_{3} \mathrm{O}_{3}$ & $325 \cdot 37$ & $78-82$ & 82 & $66 \cdot 45(66 \cdot 42)$ & $5 \cdot 89(5 \cdot 90)$ & $12 \cdot 91(12 \cdot 88)$ \\
\hline $3 \mathbf{k}$ & $\mathrm{C}_{19} \mathrm{H}_{22} \mathrm{~N}_{2} \mathrm{O}$ & $294 \cdot 40$ & $58-64$ & 90 & $77 \cdot 52(77 \cdot 54)$ & $7.53(7.51)$ & $9.52(9.50)$ \\
\hline 31 & $\mathrm{C}_{19} \mathrm{H}_{22} \mathrm{~N}_{2} \mathrm{O}$ & $294 \cdot 40$ & $90-96$ & 91 & $77.52(77.50)$ & $7.53(7.55)$ & $9.52(9.51)$ \\
\hline $3 m$ & $\mathrm{C}_{20} \mathrm{H}_{24} \mathrm{~N}_{2} \mathrm{O}$ & $308 \cdot 42$ & $108-112$ & 97 & $77.89(77.92)$ & $7.84(7.82)$ & $9.08(9 \cdot 11)$ \\
\hline $3 n$ & $\mathrm{C}_{19} \mathrm{H}_{22} \mathrm{~N}_{2} \mathrm{O}_{3}$ & $310 \cdot 52$ & $90-96$ & 96 & $73 \cdot 52(73 \cdot 51)$ & $7 \cdot 14(7 \cdot 17)$ & $9.03(9.00)$ \\
\hline 30 & $\mathrm{C}_{20} \mathrm{H}_{24} \mathrm{~N}_{2} \mathrm{O}_{2}$ & $324 \cdot 42$ & $70-74$ & 78 & $74 \cdot 04(74 \cdot 06)$ & $7 \cdot 46(7 \cdot 50)$ & $8 \cdot 64(8 \cdot 60)$ \\
\hline
\end{tabular}

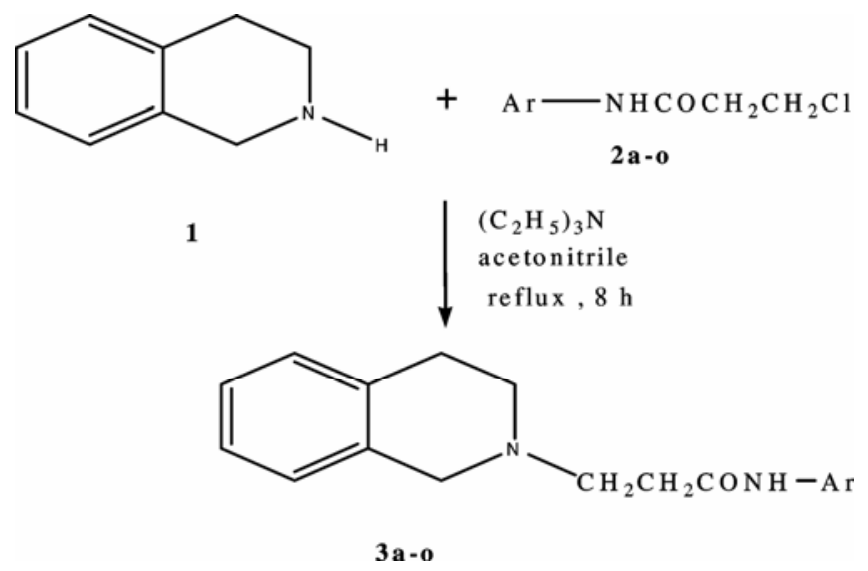

a; $\mathrm{Ar}=\mathrm{C}_{6} \mathrm{H}_{5}, \mathbf{b} ; \mathrm{Ar}=2-\mathrm{ClC}_{6} \mathrm{H}_{4}, \mathbf{c} ; \mathrm{Ar}=3-\mathrm{ClC}_{6} \mathrm{H}_{4}, \mathbf{d} ;$ $\mathrm{Ar}=o-\mathrm{CH}_{3} \mathrm{C}_{6} \mathrm{H}_{4}, \mathbf{e} ; \mathrm{Ar}=4-\mathrm{ClC}_{6} \mathrm{H}_{4}, \mathbf{f} ; \mathrm{Ar}=2,4,6-\mathrm{Br}_{3} \mathrm{C}_{6} \mathrm{H}_{2}$, g; $\mathrm{Ar}=2-\mathrm{OHC}_{6} \mathrm{H}_{4}, \mathbf{h} ; \mathrm{Ar}=3-\mathrm{OHC}_{6} \mathrm{H}_{4}, \mathbf{i} ; \mathrm{Ar}=2-\mathrm{NO}_{2} \mathrm{C}_{6} \mathrm{H}_{4}$, j; $\quad \mathrm{Ar}=4-\mathrm{NO}_{2} \mathrm{C}_{6} \mathrm{H}_{4}, \quad \mathbf{k} ; \quad \mathrm{Ar}=m-\mathrm{CH}_{3} \mathrm{C}_{6} \mathrm{H}_{4}, \quad \mathbf{l} ; \quad \mathrm{Ar}=p-$ $\mathrm{CH}_{3} \mathrm{C}_{6} \mathrm{H}_{4}, \mathbf{m} ; \mathrm{Ar}=2,4-\left(\mathrm{CH}_{3}\right)_{2} \mathrm{C}_{6} \mathrm{H}_{3}, \mathbf{n} ; \mathrm{Ar}=p-\mathrm{OCH}_{3} \mathrm{C}_{6} \mathrm{H}_{4}$, o; $\mathrm{Ar}=p-\mathrm{OC}_{2} \mathrm{H}_{5} \mathrm{C}_{6} \mathrm{H}_{4}$.

Scheme 1. Synthetic protocol of the compounds.

Linux Enterprise version 3.0 as the operating system.

The geometry of the NNBS of the wt RT strain was taken from the structure of HIV-1 RT/TNK 651 complex filed in the Brookhaven Protein Data Bank $^{53}$ (entry code 1rt2). All the residues within $20 \AA$ core from TNK 6514 were used to define the NNBS. The starting conformations for docking studies were obtained using molecular dynamics with simulated annealing as implemented in SYBYL 7.1.<smiles>CC(C)c1c(Cc2ccccc2)n(COCc2ccccc2)c(=O)[nH]c1=O</smiles><smiles>CCCCCCCCCCC#CC1(C)OC(=O)Nc2ccc(Cl)cc21</smiles>

Efavirenz (5)

Autodock 4.0.1 $1^{49-52}$ was used to explore the binding conformation of TNK $651 \mathbf{4}$ and active test molecules. The AutodockTools package version 1.4.6 was employed to generate the docking input files and to analyse the docking results. All the nonpolar hydrogens were merged and the water molecules were removed. For the docking, a grid spacing of $0.375 \AA$ and $60 \times 60 \times 60$ number of points was used. The grid was centered on the mass center of the experimental bound TNK 651 coordinates. Autodock generated 50 possible binding conformations, i.e. 50 runs for each docking by using genetic algo- 
rithm (GA-LS) searches. A default protocol was applied, with an initial population of 150 randomly placed individuals, a maximum number of $2.5 \times 10^{5}$ energy evaluations, and a maximum number of $2.7 \times 10^{4}$ generations. A mutation rate of 0.02 and a crossover rate of 0.8 were used.

To validate the use of the Autodock program, redocking was performed on the reference compound TNK 651 and for comparison purpose, cross docking was performed on the standard NNRTI Efavirenz 5. Autodock successfully reproduced the experimental binding conformations of the reference drug TNK 651 with acceptable root-mean-square deviation (RMSD) of $0.56 \AA$. The structures of the newly synthesized 3-(3,4-dihydroisoquinolin-2(1H)-yl)- $N$-(substituted phenyl)propanamides were drawn and optimized using PRODRG online server ${ }^{54}$ and saved in PDB format. These structures were used for the docking studies and the interactions of the active compounds $\mathbf{3 d}$ and $\mathbf{3 f}$ as shown in figures la and $\mathrm{b}$.

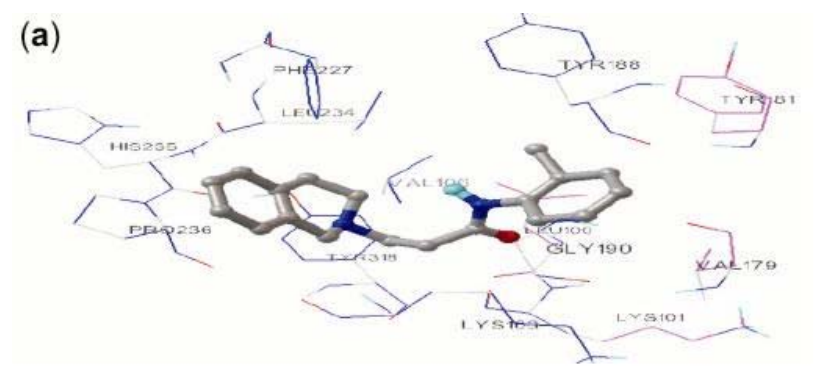

(b)

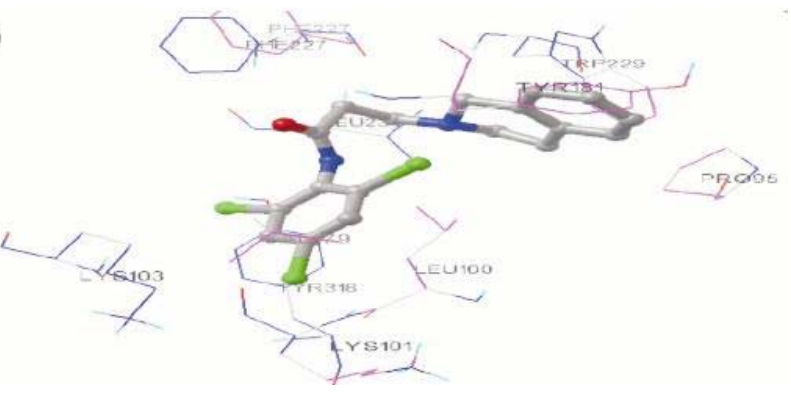

Figure 1. (a) interaction between the compound 3d (ball and stick model) and residues (coloured line model with three letter codes) within the HIV-1 RT NNBP obtained by the docking procedure. The rest of the protein structure was suppressed for clarification purposes. (b) Interaction between the compound $3 \mathbf{f}$ (ball and stick model) and residues (coloured line model with three letter codes) within the HIV-1 RT NNBP obtained by the docking procedure. The rest of the protein structure was suppressed for clarification purposes.

\section{Results and discussion}

\subsection{Synthesis of 3-(3,4-dihydroisoquinolin-2(1H)- yl)-N-(substituted-phenyl) propanamides}

Synthesis of title compound is effected by reacting the corresponding 3-chloro- $N$-(aryl) propanamide with 1,2,3,4-tetrahydroisoquinoline in presence of triethylamine by using acetonitrile as solvent. In this reaction, the liberated $\mathrm{HCl}$ is neutralized with solid anhydrous potassium carbonate, repeated washings with water and finally with $n$-hexane.

The FT-IR spectra of all the synthesized compounds and ${ }^{1} \mathrm{H}$ NMR spectra of the compounds $\mathbf{3 a}$, $\mathbf{3 d}$ and $\mathbf{3 e}$ were in complete agreement with the assigned structure. In case of IR spectral analysis, broad band in the region between 3228 and $3298 \mathrm{~cm}^{-1}$ confirms the presence of $\mathrm{NH}$ stretching of aromatic secondary amide in the title compounds. The carbonyl group appeared as sharp band in the region between 1653 and $1662 \mathrm{~cm}^{-1}$. Another band around $744 \mathrm{~cm}^{-1}$ was appeared in the compound $\mathbf{3 d}$ is mainly due to the presence of mono chloroalkanes. Appearance of absorbance band around $3650-3560 \mathrm{~cm}^{-1}$ indicates the presence of phenolic hydroxyl group in the compounds $\mathbf{3 g}$ and $\mathbf{3 h}$. A sharp absorbance band around $1579-1560 \mathrm{~cm}^{-1}$ confirms the presence of $\mathrm{C}-\mathrm{NO}_{2}$ stretching in the compounds $\mathbf{3 i}$ and $\mathbf{3} \mathbf{j}$. The compounds 3n and 3o showed absorbance band around $1219-1031 \mathrm{~cm}^{-1}$ indicates the presence of $\mathrm{C}-\mathrm{O}-\mathrm{C}$ stretching. ${ }^{1} \mathrm{H}$ NMR spectral analysis of the compounds $3 \mathbf{d}$ and $3 \mathbf{e}$ exhibited a broad singlet at $\delta 8.80$ and $11.10 \mathrm{ppm}$ respectively confirming the presence of $\mathrm{NH}$ group. Aromatic protons were appeared in the expected range of $\delta 6.80-7.30 \mathrm{ppm}$ as multiplet which confirms the presence of aromatic functional group. A triplet in the range between $\delta 2.90$ and $3.50 \mathrm{ppm}$ is mainly due to the presence of $\mathrm{N}-\mathrm{CH}_{2}$ $\mathrm{CH}_{2}-\mathrm{CONH}$ group. Compound 3d exhibited singlet at $\delta 1.90 \mathrm{ppm}$ assigned to methyl group at ortho position in the aromatic amino phenyl ring.

The FAB mass spectra of the compounds $\mathbf{3 a}, \mathbf{3 d}$ and 3e showed a molecular ion peak at $m / z 280,294$ and 315 respectively confirming the molecular weight of the appropriate title compounds.

The elemental analysis data of the all synthesized compounds were within $\pm 0.4 \%$ of the theoretical values.

\subsection{HIV-1 RT inhibitory activity}

All the synthesized compounds were evaluated for HIV-1 RT inhibitory activity using HIV-1 RT RNA 
dependent DNA polymerase activity assay. ${ }^{48}$ Efavirenz was used as the standard. The screening results indicate that compounds $\mathbf{3 d}$ and $\mathbf{3 f}$ were significantly active against HIV-1 reverse transcriptase at the final concentration of $40 \mu \mathrm{M}$ with $56 \%$ and $43 \%$ residual RT activity respectively.

\subsection{Molecular docking and binding mode analysis}

The binding mode of the active compounds $\mathbf{3 d}$ and 3f were investigated. Ligand structures were drawn and optimized using PRODRG online server and saved in PDB format. Autodock 4.0.1 program was used to dock 3d and 3f into the RT non-nucleoside inhibitor binding pocket (NNIBP). The NNIBP was obtained using the coordinates of HIV-1-RT/TNK 651 taken from the Protein Brookehaven Database (PDB entry code 1rt2).

The docking experiments were carried out using the Lamarckian genetic algorithm with local search (GA-LS) hybrid formalism of the docking program Autodock 4.0.1. Initially, the docking of TNK 6514 , which is extracted, previously from lrt2 receptor complex into the RT was performed to test the reliability and reproducibility of the docking protocol for our study. Secondly similar docking experiment was performed using standard molecule Efavirenz 5 for comparison purpose.

Autodock was able to reproduce the experimental binding conformation of $\mathbf{4}$ within a minimal root mean square deviation $(\mathrm{RMSD}=0.56 \AA$ ). The estimated binding free energy and predicted inhibitory constant value for the compound $\mathbf{3 d}$ was -10.48 and $20.86 \mathrm{nM}$ respectively. From the figure 1a, it was observed that, the tetrahydroisoquinoline moiety of 3d was oriented towards the hydrophobic pocket formed by the side chains of TYR 318, PRO 236, HIS 235 and PHE 227 and the phenyl group substituted at the ortho position with methyl group is surrounded by the residues VAL 106, LEU 100 and GLY 190 of HIV-1 RT NNIBP. For the compound 3f the estimated binding free energy and predicted inhibitory constant value was -10.36 and $25.62 \mathrm{nM}$ respectively. From the figure $1 \mathrm{~b}$, it was observed that, the tetrahydroisoquinoline moiety of $\mathbf{3 f}$ was oriented towards the side chains of TRP 229, TYR 181 and PRO 96 and the phenyl group substituted with three bromine atoms at 2 nd, 4th and 6th position is embedded into the residues of LYS 103, LYS 101, LEU 100, TYR 318 and VAL 179. These interactions may explain the significant inhibitory activi- ties of the compounds $\mathbf{3 d}$ and $\mathbf{3 f}$ at the NNIBP of HIV-1-RT. From these docking studies, it was predicted that both the active analogs $\mathbf{3 d}$ and $\mathbf{3 f}$ adopt a common type of 'butterfly-like' confirmation within the active site of NNIBP of HIV-1 RT which resembles the same binding confirmation as that of first generation NNRTIs (i.e. nevirapine, delavirdine and efavirenz).

\section{Conclusion}

In this study, some novel analogs of 3-(3,4dihydroisoquinolin-2(1H)-yl)- $N$-(substituted phenyl) propanamide were synthesized based on common pharmacophoric requirements for NNRTIs and has been confirmed by spectral and elemental analysis. All the analogs were screened for HIV-1 RT inhibitory assay. Docking studies of the most active ana$\operatorname{logs} \mathbf{3 d}$ and $3 \mathbf{f}$ were carried out to understand their exact binding mode in the active site of HIV-1 RT as well as to study their interaction with amino acid residues of HIV-1 RT. This led us to conclude that, the active analogs $\mathbf{3 d}$ and $\mathbf{3 f}$ adopt a similar 'butterfly-like' orientation like some classical NNRTIs (nevirapine, delavirdine and efavirenz) within the active site of NNIBP of HIV-1 RT. Further modifications in the phenyl portion of the tetrahydroisoquinoline nucleus in the two active analogs $3 \mathbf{d}$ and 3f could be carried out, which may lead to significantly active compounds with improved in vitro potency and in vivo efficacy against both wild and resistant strains of HIV-1.

\section{Acknowledgements}

One of the authors S M thankfully acknowledges the financial help in form of Quality Improvement Programme (QIP) Fellowship provided by All India Council of Technical Education (AICTE), New Delhi, India during the course of study. We are grateful to the Sophisticated Analytical Instrument Facility, Central Drug Research Insitute (CDRI), Lucknow, India) for providing NMR and Mass spectral data. We are also thankful to the Central Instrumentation Facility (CIF, Birla Institute of Technology, Mesra) for providing IR spectral data.

\section{References}

1. Ren-rong TIAN, Qing-jiao LIAO and Xu-lin CHEN 2007 Virologica Sinica 22(6) 476 
2. Janssen P A J, Lewi P J, Arnold E, Daeyaert F, Marc de Jonge, Heeres J, Koymans L, Vinkers M, Guillemont J, Pasquier E, Kukla M, Ludovici D, Andries $\mathrm{K}$, Marrie-Pierre de Bethune, Pauwels R, Das K, Clark A D, Frenkel Y V, Hughes S H, Medaer B, Fons De Knaep, Bohets H, Fred De Clerck, Lampo A, Williams P and Stoffels P $2005 \mathrm{~J}$. Med. Chem. 48 1901

3. Jalali-Heravi $\mathrm{M}$ and Parastar F $2000 \mathrm{~J}$. Chem. Inf. Comput. Sci. 40147

4. Das K, Lewi P J, Hughes S H and Arnold E 2005 Progress in Biophysics and Molecular Biology $\mathbf{8 8}$ 209

5. Molina A J and Arnold E 1991 Biochemistry 306351

6. Hopkins A L, Ren J S, Esnouf R M, Willcox B E, Jones E Y, Ross C, Miyasaka T, Walker R T, Tanaka H, Stammers D K and Stuart D I 1996 J. Med. Chem. 391589

7. Clercq E De 2004 Cell Biol. 361800

8. Wang M, Morin P, Wang W and Kollman P A 2001 J. Am. Chem. Soc. 1235221

9. Mitsuya H, Weinhold K J, Furman P A, St. Clair M H, Nusinoff L S, Gallo R C, Bolognesi D, Barry D W and Broder S 1985 Proc. Natl. Acad. Sci. USA 82 7096

10. Mitsuya H and Broder S 1985 Proc. Natl. Acad. Sci. US 831911

11. Yarchoan R, Mitsuya $\mathrm{H}$, Thomas R V, Pluda J M, Hartman N R, Perno C F, Merczyk K S, Allain J P, Johns D G and Broder S 1989 Science 245412

12. Coates J A V, Cammack N, Jenkinson H J, Mutton I M, Pearson B A, Storer R, Cameron J M and Penn C R 1992 Antimicrob. Agents Chemother. 36202

13. De Clercq E 1993 Med. Res. Rev. 13229

14. De Clercq E 2002 Med. Res. Rev. 22531

15. Gulick R M 2003 Clin. Microbiol. Infect. 9186

16. Tantillo C, Ding J, Molina A J, Nanni R G, Boyer P L, Hughes S H, Pauwels R, Andries K, Jannsen P A and Arnold E 1994 J. Mol. Biol. 243369

17. Silvestri R, Artico M, Massa S, Marceddu T, De Montis F and La Colla P 2000 Bioorg. Med. Chem. Lett. 10253

18. Silvestri R, Artico M, De Martino G, Rango R, Massa S, Loddo R, Murgioni C, Loi A G, La Colla P and Pani A 2002 J. Med. Chem. 451567

19. Sriram D, Bal T R and Yogeeswari P 2000 Bioorg. Med. Chem. Lett. 125865

20. Bal T R, Anand B, Yogeeswari P and Sriram D 2005 Bioorg. Med. Chem. Lett. 154451

21. Fakhfakh M A, Fournet A, Prina E, Mouscadet J F, Franck X, Hocquemiller R and Figadere B 2003 Bioorg. Med. Chem. 115013

22. Benard C, Zouhiri F, Normand-Bayle M, Danet M, Desmaele D, Leh H, Mouscadet J F, Mbemba G, Thomas C M, Bonnenfant S and M. Bret L J 2004 Bioorg. Med. Chem. Lett. 142473

23. Kireev D B, Chretien J R and Raevsky O A 1995 Eur. J. Med. Chem. 30395

24. Monga V, Nayyar A, Vaitilingam B, Palde B, Singh J S, Kaur S, Singh P and Jain R 2004 Bioorg. Med. Chem. 126465
25. Sadana A K, Mirza Y, Aneja K R and Prakash O M 2003 Eur. J. Med. Chem. 38533

26. Nayyar A, Monga V, Malde A, Coutinho E and Jain R 2007 Bioorg. Med. Chem. 15626

27. Kayirere M G, Mahamoud A, Chevalier J, Soyfer J C, Cremieux A and Barbe J 1998 Eur. J. Med. Chem. 33 55

28. Musiol R, Jampilek J, Buchta V, Silva L, Niedbala H, Podeszwa B, Palka A, Majerz-Maniecka K, Oleksyn B and Polanski 2006 Bioorg. Med. Chem. 143592

29. Holla B S, Mahalinga M, Karthikeyan M S, Akberali P M and Shetty N S 2006 Bioorg. Med. Chem. Lett. 142040

30. Sahu N P, Pal C, Mandal N B, Banerjee S, Raha M, Kundu A P, Basu A, Ghosh M, Roy K and Bandyopadhyay S 2002 Bioorg. Med. Chem. 101687

31. Franck $X$, Fournet A, Prina E, Mahieux R, Hocquemiller R and Figadere B 2004 Bioorg. Med. Chem. Lett. 143635

32. Boa A N, Canavan S P, Hirst P R, Ramsey C, Stead A M W and McConkey G A 2005 Bioorg. Med. Chem. 131945

33. Martinez-Grueiro M, Gimenez-Pardo C, GomezBarrio A, Franck X Fournet A, Hocqquemiller R, Figadere B and Casado-Escribano N 2005 Il-Farmaco 60219

34. Elslager E F, Perricone S C and Tendick F H 1996 J. Med. Chem. 12965

35. Elslager E F, Tendick F H, Werbel L M and Worth D F 1969 J. Med. Chem. 12970

36. Heindel N E D, Bechara I S, Ohnmacht C J, Molnar J, Lemke T F and Kennewell P D $1969 \mathrm{~J}$. Med. Chem. 12797

37. Tara Singh, Stein R G and Biel J H 1969 J. Med. Chem. 12801

38. Ohnmacht C J, Patel A R and Lutz R E $1971 \mathrm{~J}$. Med. Chem. 14926

39. Tara Singh, Stein R G, Hoops J F, Biel J H, Hoya W $\mathrm{K}$ and Cruz D R 1971 J. Med. Chem. 14283

40. Raynes K J, Stocks P A, O'Neill P M, Park B K and Ward S A 1999 J. Med. Chem. 422747

41. Stocks P A, Raynes K J, Bray P G, Kelvin Park B, O'Neill P M and Ward S A 2002 J. Med. Chem. 45 4975

42. Marian F, Isabella F, Philippe G, Christian S and Rebecca D P 2003 Bioorg. Med. Chem. Lett. 13 2659

43. Madrid P B, Sherril John, Liou A P, Weisman J L, Derisi J L and R. K. Guy R K 2005 Bioorg. Med. Chem. Lett. 151015

44. Raja Solomon V, Puri S K, Srivastava K and Katti S B 2005 Bioorg. Med. Chem. 132157

45. Musonda C C, Gut J, Rosenthal P J, Yardley V, Carvalho R C and Chibale K 2006 Bioorg. Med. Chem. 145605

46. Barlaam and Benard, PCT. Int. Appl. Wo-2004, 108, 703 (Cl. Co7D401/12), 16-December 2004

47. Ganguly S and Somakala K 2007 J. Institution Chemists (India) 79(6) 33

48. De Martino G, La Regina G, Di Pasquali A, Rango R, Bergamini A, Ciaprini C, Sinistro A, Maga G, 
Crespan E, Artico M and Silvestri R 2005 J. Med. Chem. 484378

49. Goodsell D S, Morris G M and Olson A J $1996 \mathrm{~J}$. Mol. Recognit. 91

50. Morris G M, Goodsell D S, Halliday R S, Huey R, William E, Hart W E, Belew R K and Olson A J 1998 J. Comput. Chem. 191639

51. Sousa S F, Fernandes P A and Ramos M J 2006 Proteins $\mathbf{6 5} 15$
52. Huey R, Morris G M, Olson A J and Goodsell D S 2007 J. Comput. Chem. 281145

53. Hopkins A L, Ren J, Esnouf R M, Willcox B E, Jones E Y, Ross C, Miyasaka T, Walker R T, Tanaka H, Stammers D K and Stuart D I $1996 \mathrm{~J} \mathrm{Med.} \mathrm{Chem.}$ 39(8) 1589

54. Schuettelkopf A W and Van Aalten M F 2004 Acta Crystallographica D60 1355 http://davapc1.bioch. dundee.ac.uk/prodrg/index.html 